\title{
SMART WASTE MANAGEMENT FOR LOW- CARBON SOCIETY IN MULTIMEDIA SUPER CORRIDOR CITY - CYBERJAYA, MALAYSIA
}

\author{
Siti Norbaizura MD REJAB ${ }^{1 *}$, Tomohito HAMADA ${ }^{1}$ and Takeshi FUJIWARA ${ }^{2}$ \\ ${ }^{1}$ Dept. of Sustainability of Resources, Okayama University \\ (3-1-1, Tsushima-Naka, Kita-ku, Okayama, 700-8530 Japan) \\ 2 Solid Waste Management Research Center, Okayama University \\ (3-1-1, Tsushima-Naka, Kita-ku, Okayama, 700-8530 Japan) \\ *E-mail:gev421308@s.okayama-u.ac.jp
}

\begin{abstract}
Compares to other middle income developing countries, Malaysia is emitting a significant amount of greenhouse gases (GHG) that causes global warming. Feasibility study on building a low-carbon society in its Multimedia Super Corridor city, Cyberjaya Digital Green City 2025 (DGC2025) was launched following the study of Putrajaya Green City 2025. The main objective of these studies is to build the cities to become a pioneer township in Green Technology. Smart 3R Cyberjaya is one of DGC2025 four themes and focuses on planning alternative solid waste management that fulfil the challenge of building both low-carbon and sound material society. Smart 3R Cyberjaya set the target of building a zero emission society that depend less on landfill and actively practicing waste reduction at source. This is quantitatively represent as $75 \%$ reduction of waste sent to landfill site and 50\% reduction of total greenhouse gases emission, compare to 2025 business as usual scenario. Three counter measure scenarios were evaluated from combination of waste reduction at source; $2 \mathrm{R}$ actions and waste treatment selection; food disposer, recycling and thermal treatment. Solid wastes modelled in our scenarios are household solid waste, business solid waste, sludge, green waste and electrical and electronic waste (e-waste). In 2025 , total waste generation is 207 ton/day and 1041 ton/year of e-waste. Both waste and GHG reduction target is achievable at 2025CM3 scenarios, $78 \%$ (172 t/day) and 84\% (1459 t-CO2/day), respectively. Results of other scenarios could also give us a new image of alternative future society.
\end{abstract}

Key Words: 3R, solid waste management, sound-material cycle society, low-carbon society, Malaysia

\section{INTRODUCTION}

"Think globally, act locally" phrase was first applied in town planning field to represent the needs to be aware of not only global but also urban and rural differences in every planning ${ }^{1}$. Since then the phrase has been widely implemented in various field including environmental. It is best defined as urging people to consider the health of the entire planet and to take action on their own communities and cities ${ }^{1}$.

This concept is also represented in the report of Malaysia Economic Monitor - Smart Cities that give a strong consideration of Malaysia's own need and ability to keep taking part in global market. The report portrays Malaysia's Smart Cities as Innovative, Green and Resilient, and uses greenhouse gases (GHG) and solid waste management as benchmark for Smart Green Cities.
The World Bank also stated that "it involves taking stock of the existing urban environmental problems, their comparative analysis and prioritization, setting out objectives and targets, and identification of various measures to meet the objectives of addressing the complex urban environmental problems" ${ }^{22}$.

In this study of building a Smart 3R city that practices a sound-material cycle within low-carbon prospect, we are also presenting our model using the two indicators; GHG and solid waste amount.

\section{BACKGROUND}

\section{(1) Overview of Cyberjaya Malaysia}

Cyberjaya is a town with a science park as the core that forms a key part of the Multimedia Super 
Corridor (MSC) in Malaysia. The city aspires to be known as the Silicon Valley of Malaysia. The establishment of the MSC program was crucial to accelerate the objectives of Vision 2020 and to transform Malaysia into a modern state by the year 2020, with the adoption of a knowledge-based society framework. MSC Malaysia covers an area of approximately $750 \mathrm{~km}^{2}$ stretching from the Petronas Twin Towers to the Kuala Lumpur International Airport, and including the towns of Putrajaya and Cyberjaya.

Cyberjaya the core of Malaysia MSC covers an area of $29 \mathrm{~km}^{2}$ freehold land that consist four main zones known as enterprise, commercial, institutional and residential. It is now the home for over 500 MSC Status companies, several tertiary education institutes, and residential for both living in and commuting people of the city. By 2025 , the city is also expected to see a large boom in population growth with residential developments to cater up to a target population of 210,000 , business developments providing for up to 120,000 employees and institutional establishments for 30,000 students $^{3)}$.

\section{(2) Feasibility study of Cyberjaya Digital Green City 2025}

During $15^{\text {th }}$ Conference of Parties, Copenhagen, held in December 2009, Malaysia Prime Minister (PM) announced that Malaysia is adopting an indicator of a voluntary reduction $40 \%$ in terms of GHG emission intensity of gross domestic products by 2020 compared to 2005 level. The PM also said that Malaysia is committed to ensure at least half of its land area remained as forest as pledged at the Rio Summit ${ }^{4}$. These two announcements then bring to another announcement in 2010 budget speech by The PM and Minister of Finance of Developing Green Technology. In item 54 of the speech, stated "develop Putrajaya and Cyberjaya as pioneer townships in Green Technology, as a showcase for the development of other townships"5).

Ministry of Energy, Green Technology and Water, Malaysia as the key stakeholder of promoting the importance of green technology in sustainable development has been promoting measures such as "National Green technology Policy" and Feed-in Tariff". Besides that, in September 2011, "Low Carbon City Framework" was launched by The PM. This is a green rating system based on the carbon footprint baseline, and a $10 \%$ saving in energy and water in all government buildings ${ }^{6)}$.

In October 2010 Putrajaya Corporation, local authority of Putrajaya proposed a preliminary study of 'Putrajaya Green City 2025' (PGC2025) which was carried out under three elements of environment: 'Low-Carbon Putrajaya' 'Cooler Putrajaya' and '3R Putrajaya'. Each element presents its own target with the study target to achieve a low-carbon society by the target year of $2025^{7}$. Following the completion of PGC2025, Cyberjaya developer, Cyberview also proposed the interest in carrying out a preliminary study in Cyberjaya. For 'Cyberjaya Digital Green City 2025' (DGC2025), four themes were introduced: 'Lowcarbon Cyberjaya', 'Smart 3R Cyberjaya', 'Liveable \& Vibrant City' and 'Smart Digital Network City'. Towards realizing DGC2025 through the four themes, a 'Dozen Actions' table was formulated as a concrete vision for such society. Two out of the four actions are represented quantitatively; 'Low-carbon Cyberjaya' and 'Smart 3R Cyberjaya' with reduction of $50 \% \mathrm{CO}_{2}$ emission and $75 \%$ solid waste sent to landfill by the year of 2025 compared to Business as Usual (BaU), respectively.

\section{METHOD}

\section{(1) Scenario building}

This paper focuses on 'Smart 3R Cyberjaya' with the targets to reduce $75 \%$ of solid waste amount sent to landfill by the year of 2025 compared to $2025 \mathrm{BaU}$ where in $2010 \mathrm{CM}$ (counter measure) scenario, only $5 \%$ of generated waste is being recycled and the rest are directly sent to landfill site for final disposal. 'Smart 3R Cyberjaya' covers the entire scope of waste management from waste generation to waste final disposal (Fig.1). On top of that, we did not only considered municipal solid waste (MSW) (household solid waste (HSW) and business solid waste (BSW)) but also green waste from park and garden, sewage sludge, and electrical and electronic equipment waste (e-waste). In order to evaluate our target of $75 \%$ waste reduction, we proposed three alternatives solid waste management (SWM) scenarios for MSW. The scenarios are as follows:

\section{(i) Business as usual (BaU)}

All waste generated is sent directly to final landfill site without any pre-treatment process. This is the current scenario for waste handling in the study area.

\section{(ii) Low level of enforcement (2025CM1)}

Waste management with $3 \mathrm{R}$ actions are introduced and carried out. Both public participation and efficiency of carrying out actions are set at low level. In this scenario for MSW, except for thermal treatment, participation and efficiency are set at $50 \%$ level. In the thermal treatment action 


\section{(2) Modelling}

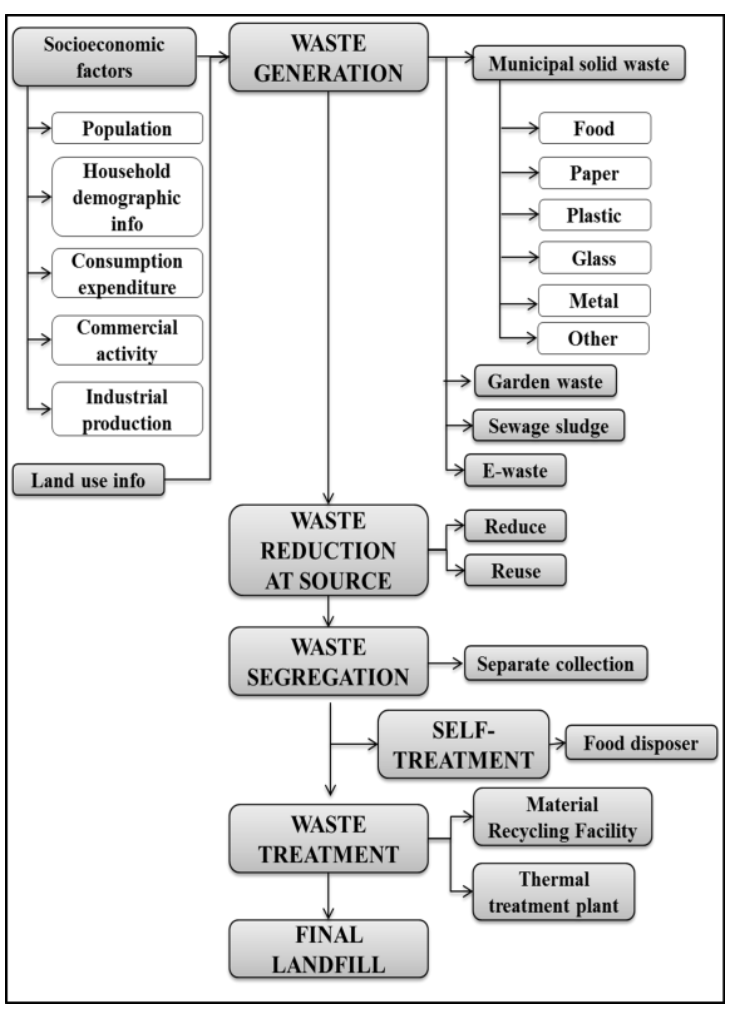

Fig.1 Study flow.

participation and efficiency are set at $90 \%$ and 50\% respectively. At low level waste management scenario only Reduce and Reuse actions (2R) rated 3 will be calculated.

(iii) Moderate level of enforcement (2025CM2)

Waste management with $3 \mathrm{R}$ actions are introduced and carried out. Both public participation and efficiency of carrying out actions are set at moderate level. In this scenario for MSW, except for thermal treatment, participation and efficiency are set at $75 \%$. In the thermal treatment action participation and efficiency are set at $90 \%$ and $75 \%$ respectively. At moderate level waste management scenario only $2 \mathrm{R}$ actions rated 3 and 1 will be calculated.

(iv) High level of enforcement (2025CM3)

Waste management with $3 \mathrm{R}$ actions are introduced and carried out. Both public participation and efficiency of carrying out actions are set at high level. In this scenario for MSW, for all actions, participation and efficiency are set at $100 \%$ and $90 \%$, respectively. At high level waste management scenario all $2 \mathrm{R}$ actions will be calculated.

\section{a) Waste generation}

(i) Household solid waste (HSW)

Using socio-economic indicators provided by Cyberview (land owner of Cyberjaya) through their Cyberjaya City Survey 2010 "Outcome of Report" and The Study on National Waste Minimisation in Malaysia (TNS), we projected HSW generation for base year 2010. HSW generation for target year 2025 are projected using socio-economic indicators from Setia Haruman (master developer of Cyberjaya) ${ }^{9)}$ and TNS. Combination of night time and student population for base and target year is 33,574 and 240,000 , respectively. Total waste generation for Cyberjaya is calculated using urban per capita generation rate of $0.71 \mathrm{~kg} / \mathrm{day}$ and the composition of $40 \%$ food, $31 \%$ paper, $8 \%$ plastic, $4 \%$ glass, $2 \%$ metal and $15 \%$ other ${ }^{10)}$. Product and packaging waste classification are projected using the Report on Household Expenditure Survey ${ }^{11,12}$, National Input-Output Table ${ }^{13,14)}$ and Annual Survey of Manufacturing Industries ${ }^{15)}$. The generation coefficients are paper $(0.02,0.98)$, plastic $(0.26$, $0.74)$, glass $(0.14,0.86)$, and metal $(0.43,0.57)$, with the former is product and the latter is packaging waste generation coefficient.

\section{(ii) Business solid Waste (BSW)}

Employment number for 2010 and 2025 is 12,838 and 120,000, respectively, and from the same source as HSW. TNS stated that urban per capita generation of BSW is $0.30 \mathrm{~kg} /$ day with $18 \%$ food, $32 \%$ paper, $9 \%$ plastic, $8 \%$ glass, $4 \%$ metal and $29 \%$ other. In order to calculate waste reduction via $2 \mathrm{R}$ actions, we have to project product and packaging waste classification. Product and packaging waste classification for business sector are projected using National Input Table 2010 ${ }^{16)}$ and Report on the Annual Survey of Manufacturing Industries. Business expenditures are categorized into seven groups based on information from few office item suppliers. The seven groups are personal computer (PC) related goods, office device, file and cases, clerical device, writing material, packaging and operational goods, and living ware ${ }^{17)}$. After the categorization, we classify the expenditure type into its related manufacturing industries. Table 1 summarized the manufacturing group and its contribution in each division (manufacturing activity) based on the annual survey of manufacturing industries. Which were then used to project generation coefficient of product and packaging waste (Table 2). The generation coefficients are paper $(0.45,0.55)$, plastic $(0.41$, $0.59)$, glass $(0.38,0.62)$, and metal $(0.87,0.13)$, with 
Table 1 Share composition of various industries in Malaysia manufacturing

\begin{tabular}{|c|c|c|}
\hline Description & Industry Code & Composition $(\%)$ \\
\hline Manufacture of paper and paper products & 170 & \\
\hline Manufacture of pulp, paper and paperboard & 17010 & 0.24 \\
\hline Manufacture of corrugated paper and paperboard and of containers of paper & & \\
\hline and paperboard & 17020 & 0.43 \\
\hline Manufacture of envelopes and letter-card & 17091 & 0.03 \\
\hline Manufacture of household and personal hygiene paper & 17092 & 0.17 \\
\hline Manufacture of gummed or adhesive paper in strips or rolls and labels and & & \\
\hline wallpaper & 17093 & 0.09 \\
\hline Manufacture of effigies, funeral paper goods, joss papers & 17094 & 0.02 \\
\hline Manufacture of other chemical products & 202 & \\
\hline Manufacture of soap and detergents, cleaning and polishing preparations & 20231 & 0.13 \\
\hline Manufacture of perfumes and toilets preparations & 20232 & 0.09 \\
\hline Manufacture of plastic products & 222 & \\
\hline Manufacture of plastic articles for the packaging of goods & 22203 & 0.29 \\
\hline Manufacture of other fabricated metal products; metal working service activities & 259 & \\
\hline Manufacture of tins and cans for food products, collapsible tubes and boxes & 25991 & 0.15 \\
\hline Manufacture of general-purpose machinery & 281 & \\
\hline $\begin{array}{l}\text { Manufacture of office machinery and equipment (excepts computers and } \\
\text { peripheral equipment) }\end{array}$ & 28170 & 0.02 \\
\hline Other manufacturing & 329 & \\
\hline Manufacture of stationery & 32901 & 0.66 \\
\hline
\end{tabular}

the former is product and the latter is packaging waste generation coefficient.

\section{(iii) Sewage sludge}

Data from sewage treatment plants in Cyberjaya was not accessible during the modelling proposed. As an alternative, the generation rate of sludge was calculated based on data provided by local authority of Putrajaya during PGC 2025 study. We make an assumption that sewage sludge per capita generation of Malaysian is fix. Sewage generation rate of Putrajaya is $0.22 \mathrm{~m}^{3} /$ capita/day with sludge ratio of 0.0002 ton $/ \mathrm{m}^{318)}$.

\section{(iv) Green waste from park and garden}

Using land use data provided by Setia Haruman the master developer of Cyberjaya, we learnt that Cyberjaya is composed of 282.79 hectare of green area in 2025 . We calculated green waste generation using two generation factors: grass cutting and branch tipping, with the former producing 4.6 $\mathrm{kg} / \mathrm{ha} /$ day and the latter are $11 \mathrm{~kg} / \mathrm{ha} / \mathrm{day}^{18)}$.

\section{(v) Electrical and electronic equipment waste}

In 2007, Department of Environment, Malaysia carried a study on The E-waste Inventory Project in Malaysia (e-waste study) ${ }^{19}$. In Malaysia, under Environmental Quality (Scheduled Waste) Regulation 2005 waste from the assembly of electrical or electronic appliances that consist of components such as accumulators, mercuryswitches, glass from cathode-ray tubes and other activated glass or polychlorinated biphenylcapacitors, or contaminated with cadmium, mercury, lead, nickel, chromium, copper, lithium, silver, manganese or polychlorinated biphenyl are listed as e-waste ${ }^{20)}$. The e-waste study focused on seven selected types of e-waste that is television sets (TV), personal computers (PC), mobile phones, refrigerators, air conditioners (AC), washing machines and rechargeable batteries. Since this study is the only e-waste related data that we can get, e-waste generation in Cyberjaya is calculated using result of this study. According to Cyberjaya planning by 2025, 500 MSC status companies and several tertiary education institutes will be base in Cyberjaya. Using these information we projected 2025 e-waste amount generated in Cyberjaya with the 9 education institute counted as large scale institution and the rest of companies are 50\% small and $50 \%$ small scale. According to the e-waste study small, medium and large business are represented by 5 to 50,51 to 150 , and more than 150 employers, respectively. E-waste generation rate by business activity scale are as Table $\mathbf{3}$.

\section{(b) Waste reduction at source}


Table 2 Product and packaging waste classification based on expenditure type and manufacturing activity

\begin{tabular}{|c|c|c|c|}
\hline Expenditure type & Manufacture & Description & $\begin{array}{l}\text { Waste } \\
\text { Classification }\end{array}$ \\
\hline \multirow[t]{2}{*}{$\begin{array}{l}\text { Personal computer } \\
\text { related goods }\end{array}$} & $\begin{array}{l}\text { Manufacture of radio, television and } \\
\text { communication equipment and } \\
\text { apparatus }\end{array}$ & $\begin{array}{l}\text { Manufacture of recording and reproducing } \\
\text { apparatus }\end{array}$ & Product \\
\hline & $\begin{array}{l}\text { Manufacture of electrical machinery } \\
\text { and apparatus }\end{array}$ & Manufacture of insulated wire and cable & Product \\
\hline Office device & $\begin{array}{l}\text { Manufacture of general-purpose } \\
\text { machinery }\end{array}$ & $\begin{array}{l}\text { Manufacture of office machinery and } \\
\text { equipment (excepts computers and } \\
\text { peripherals equipment) }\end{array}$ & Product \\
\hline File and cases & Other manufacturing & Manufacture of stationer & Product \\
\hline \multirow{2}{*}{$\begin{array}{l}\text { Clerical device } \\
\text { Writing material }\end{array}$} & $\begin{array}{l}\text { Manufacture of paper and paper } \\
\text { products }\end{array}$ & $\begin{array}{l}\text { Manufacture of pulp, paper and paperboard } \\
\text { Manufacture of envelopes and letter-card } \\
\text { Manufacture of gummed or adhesive paper } \\
\text { in strips or rolls and labels wallpaper }\end{array}$ & Product \\
\hline & Other manufacturing & Manufacture of stationery & Product \\
\hline \multirow[t]{3}{*}{$\begin{array}{l}\text { Packaging and } \\
\text { operational goods }\end{array}$} & $\begin{array}{l}\text { Manufacture of paper and paper } \\
\text { products }\end{array}$ & $\begin{array}{l}\text { Manufacture of corrugated paper and } \\
\text { paperboard, and of containers of paper and } \\
\text { paperboard }\end{array}$ & Packaging \\
\hline & Manufacture of plastic products & $\begin{array}{l}\text { Manufacture of plastic articles for } \\
\text { packaging of goods }\end{array}$ & Packaging \\
\hline & $\begin{array}{l}\text { Manufacture of other fabricated metal } \\
\text { products, metal working service } \\
\text { activities }\end{array}$ & $\begin{array}{l}\text { Manufacture of tins and cans for food } \\
\text { products, collapsible tubes and boxes }\end{array}$ & Packaging \\
\hline \multirow[t]{2}{*}{ Living ware } & $\begin{array}{l}\text { Manufacture of other chemical } \\
\text { products }\end{array}$ & $\begin{array}{l}\text { Manufacture of soap and detergents, } \\
\text { cleaning and polishing preparations, } \\
\text { manufacture of perfumes and toilet } \\
\text { preparations }\end{array}$ & Packaging \\
\hline & $\begin{array}{l}\text { Manufacture of paper and paper } \\
\text { products }\end{array}$ & $\begin{array}{l}\text { Manufacture of household and personal } \\
\text { hygiene paper }\end{array}$ & Product \\
\hline
\end{tabular}

For projection of waste reduction at source, we asked various stake holders of Cyberjaya to rate two sets of waste $2 \mathrm{R}$ actions each prepared for household and business sector. In the household sector, 11 sub-actions are group under three actions namely smart purchase, waste refuse and smart planning. Respondents were asked to rate these actions with regard to reduction of household consumption from 0 for actions that had no effect, 1 for little effect, 2 for moderate effect, and 3 for the most important actions. From 12 expenditure groups, six were picked out as major waste-generating

Table 3 E-waste generation rate by business

\begin{tabular}{lrrrr}
\multicolumn{4}{c}{ activity scale } & \multicolumn{2}{c}{$\begin{array}{c}\text { Average } \\
\text { weight (kg) }\end{array}$} \\
\cline { 2 - 4 } & \multicolumn{3}{c}{ Use pattern (Unit) } & 35 \\
Small & Medium & Large & \\
Mobile & 1.1 & 2 & 5.3 & 0.1 \\
phone & 3.3 & 10.7 & 77.8 & 30 \\
PC & 9.6 & 68.1 & 220.4 & 70 \\
Refrigerator & 1.6 & 2 & 0.1 & 60 \\
AC & 3.9 & 13.8 & 14.5 & 50 \\
Washing & & & & \\
Machine & 2.9 & 1 & 1.5 & \\
\hline & & & &
\end{tabular}

factors. The six expenditure groups are 'food', 'beverages', 'clothing and footwear', 'furnishing, household equipment and routine household maintenance', 'recreation, services and culture', and 'miscellaneous goods and services'.

The same rating method is applied for business sector. However, in the business sector, 25 subactions are group under 5 categories namely general, paper, break room, building maintenance, and shipping, receiving and distribution. Table 4 and Table 5 summarized both sectors action and subactions. Calculation of waste reduction from $2 \mathrm{R}$

Table 4 2R actions for household sector

\begin{tabular}{ll}
\hline Action & Sub-action \\
\hline Smart purchase & Buy according to need \\
& Buy in bulk \\
& Buy refill and concentrates \\
& Buy local products \\
Waste refuse & Not to buy over packaged products \\
& Do not take plastic bag \\
& Use my shopping bag \\
Smart planning & Rent or borrow instead of buying \\
& Sharing \\
& Choose for durable items \\
& Choose for reusable items \\
\hline
\end{tabular}


Table 5 2R actions for business sector

\begin{tabular}{llll}
\hline Group & Sub-action & Group & Sub-action \\
\hline General & Plan purchase to avoid leftover & Break room & Use reusable utensil \\
& Choose refillable items & & Bring lunches in reusable container \\
& Choose multi-purpose items & & Set-up a food waste composting program \\
& Use rechargeable battery & Building maintenance & Use a multipurpose product \\
& Use rewritable computer media & & Use metered dispenser \\
& Buy recycled products & & Use concentrate and refillable applicator \\
& & & Use cloth roll towel / air dryer in the \\
& Use rental and lease service & & restrooms instead of paper product \\
Paper & Priority to digital documentation & Shipping, receiving and & Buy supplies in bulk or economy size \\
& Limit printout number per employee & & packaging \\
& Set printer to double-sided printing & & Ask for minimal packaging option \\
mode & & Ship product in returnable, reusable \\
Set a one-sided paper corner & & Rentainer \\
& & & Use shredded office paper or discarded \\
& Use central filing system & material for packaging
\end{tabular}

actions for both household and business sector is represented in the following equation:

$W_{2 R}=\left(\alpha \times P_{i} \times E_{i}\right) \times W_{B a U}$

$\alpha$ indicates the effect of actions rating on waste generation; $P_{i}$ indicates participation level; $E_{i}$ indicates efficiency level in response with counter measure scenarios $(i=1,2,3)$. All waste types except food are calculated.

\section{(c) Self-treatment}

Cyberjaya with its role as the core of Malaysia MSC is moving towards building a high-technology community. In line with this, we projected scenario of self-treatment using food disposer in each household compared to a more nature basis selection of composting that introduced in PGC2025. Under this action, disposer instalment is introduced to household depending on the enforcement level. However, for business sector, food waste generated will be sent directly to treatment facility. Amount of waste reduced from self-treatment action $\left(W_{S f}\right)$ is calculated as in Eq. (2), where $E n_{i}$ indicates enforcement level in response with counter measure scenario.

$W_{S f}=\left(E n_{i} \times E_{i}\right) \times W_{B a U}$

\section{(d) Separate collection}

In Malaysia generally waste collection and transportation is contracted to be handle by private concessionaire. However, this is not true for Cyberjaya that is under jurisdiction of Sepang Local Authority (LA). Waste collection is carried out by contractor appointed by Sepang LA. In term of waste separation, we proposed separate collection that meets the requirement of thermal treatment that is also modelled for DGC2025. This action includes both household and business waste. Waste types estimated under this action are paper and plastic product waste, and paper, plastic, glass and metal packaging waste, with calculation equation as follows:

$W_{S c}=\left(P_{i} \times E_{i}\right) \times\left(W_{2 R_{\text {Prod }}}+W_{2 R_{\text {Pack }}}\right)$

Where;

$W_{S c} \quad$ : Amount of waste reduced from separate collection action

$W_{2 R_{\text {Prod }}}$ : Amount of product waste generated after waste reduction at source; paper and plastic

$W_{2 R_{\text {Pack }}}$ : Amount of packaging waste generated after waste reduction at source; paper, plastic, glass and metal

\section{(e) Thermal treatment}

On top of separate collection of recyclable materials, combustible waste is considered to be treated using thermal treatment such as incineration. Product and packaging waste of paper, plastic, and glass from household and business sector are considered for this action. On top of that, food waste from business sector is also treated using thermal treatment. Calculation of waste reduction using thermal treatment $\left(W_{T t}\right)$ is: 


$$
W_{T t}=\left(P_{i} \times E_{i}\right) \times\left(W_{S c_{\text {Prod }}}+W_{S c_{\text {Pack }}}\right)
$$

Where;

$W_{2 R_{\text {Prod }}}$ : Amount of product waste generated after separate collection action; food from business waste, paper, plastic and glass

$W_{2 R_{\text {Pack }}}$ : Amount of packaging waste generated after separate collection action; paper, plastic and glass

\section{(f) Final landfill}

After all waste reduction and treatment consideration remaining waste is sent to currently available landfill site. Besides the remaining waste, residual from waste treatment facility such as thermal treatment and construction waste are also sent to landfill site.

$$
\begin{gathered}
W_{L d}=W_{B a U}-\left(W_{2 R}+W_{S f}+W_{S c}+W_{T t}\right) \\
+W_{R}
\end{gathered}
$$

where, $W_{L d}$ is amount of waste sent to landfill site and $W_{R}$ is residual from waste treatment facility.

\section{(3) Greenhouse Gases Calculation}

Greenhouse gases are one of the major indicators of environmental quality. According to the report of Malaysia Economic Monitor - Smart Cities stated that Malaysia's GHG emissions are relatively high for a country at its level of income and development.
Not only that its per capita GHG emissions were significantly higher than other middle income countries, but also Malaysia is now a net emitter not a net emission.

In this study we calculated GHG emitted from waste treatment facility and compare it with GHG emitted from landfill; the only waste treatment selection at $\mathrm{BaU}$ scenario. Our calculation considers not only $\mathrm{CO}_{2}$ but also $\mathrm{CH}_{4}, \mathrm{~N}_{2} \mathrm{O}, \mathrm{NO}_{\mathrm{X}}, \mathrm{SO}_{\mathrm{X}}$ and smoke dust ${ }^{21,22)}$.

\section{RESULT AND DISCUSSION}

Household population in Cyberjaya were calculated from two types of population; night time population and student population. In base year of 2010 , the former is 13,353 and the former is 20 , 221 people. In 2025, major increase of 16 times night time population and 1.5 times student population will caused HSW generation to hike from $22.7 \mathrm{t} /$ day to $170.4 \mathrm{t} / \mathrm{day}$. In term of business sector increase of 9.3 times employment number caused BSW increase from $3.7 \mathrm{t} /$ day to $36.5 \mathrm{t} /$ day. Waste generation of sewage sludge, green waste and e-waste is 8.9 t/day, 4.5 t/day and 1041 t/year, respectively. Table 6 shows detail composition on MSW in BaU2010 and BaU2025 based from our product and packaging waste classification using household/business expenditure and manufacturing demand. Our calculation results show that for both MSW generation of packaging waste is bigger than product waste except for metal in BSW.

Fig.2 shows the comparison of our alternative

Table 6 Result of municipal solid waste generation (ton/day) for business as usual case

\begin{tabular}{lrrrrrr}
\hline & \multicolumn{3}{c}{$\mathbf{2 0 1 0}$} & \multicolumn{4}{c}{$\mathbf{2 0 2 5}$} \\
\cline { 2 - 7 } & \multicolumn{2}{c}{ BaU } & \multirow{4}{*}{ Botal } & \multicolumn{1}{c}{ BSW } & \multicolumn{1}{c}{ BSW } & Total \\
\hline Food & 8.99 & 0.67 & 9.66 & 67.65 & 6.60 & 74.25 \\
Paper & 7.07 & 1.20 & 8.27 & 53.16 & 11.82 & 64.98 \\
Product & 0.12 & 0.54 & 0.66 & 0.92 & 5.29 & 6.20 \\
Packaging & 6.94 & 0.66 & 7.61 & 52.25 & 6.53 & 58.78 \\
Plastic & 1.83 & 0.33 & 2.16 & 13.80 & 3.21 & 17.01 \\
Product & 0.47 & 0.13 & 0.60 & 3.55 & 1.31 & 4.86 \\
Packaging & 1.36 & 0.19 & 1.56 & 10.25 & 1.90 & 12.15 \\
Glass & 0.79 & 0.29 & 1.08 & 5.96 & 2.81 & 8.77 \\
Product & 0.11 & 0.11 & 0.22 & 0.81 & 1.06 & 1.88 \\
Packaging & 0.68 & 0.18 & 0.86 & 5.15 & 1.75 & 6.90 \\
Metal & 0.50 & 0.14 & 0.64 & 3.75 & 1.39 & 5.14 \\
Product & 0.21 & 0.12 & 0.34 & 1.60 & 1.21 & 2.81 \\
Packaging & 0.29 & 0.02 & 0.30 & 2.15 & 0.18 & 2.33 \\
Other & 3.46 & 1.08 & 4.55 & 26.07 & 10.65 & 36.72 \\
\hline Total & $\mathbf{2 2 . 6 5}$ & $\mathbf{3 . 7 1}$ & $\mathbf{2 6 . 3 5}$ & $\mathbf{1 7 0 . 4 0}$ & $\mathbf{3 6 . 4 8}$ & $\mathbf{2 0 6 . 8 8}$ \\
\hline
\end{tabular}




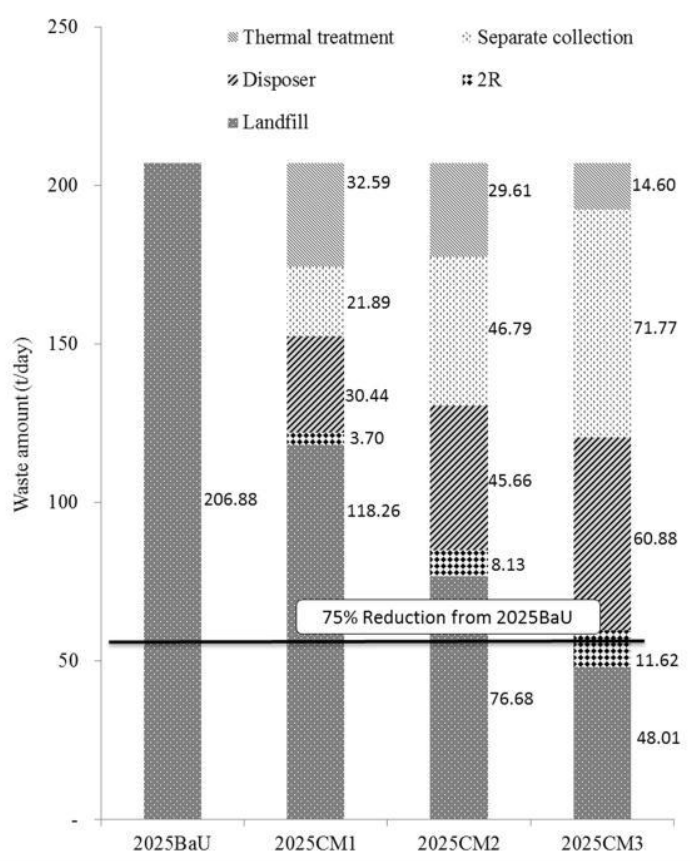

Fig.2 Waste amount by reduction action

SWM scenarios. The study target of reducing $75 \%$ solid waste amount sent to landfill by the year of 2025 compared to $\mathrm{BaU}$ is achievable under scenario CM3 at 78\% (172 t/day). Even though CM1 and $\mathrm{CM} 2$ waste reduction are below the target, reduction amount from both actions are significant compare to base year, 2010. In 2010 3R rate in Malaysia is as small as $5 \%$ but CM1 and CM2 reduction is $46 \%$ (102 t/day) and 65\% (144 t/day), respectively. The most GHG reduction from alternatives scenario is also under $\mathrm{CM} 3$ at $84 \%$ (1459 $\mathrm{t}-\mathrm{CO}_{2} /$ day) follows by $\mathrm{CM} 2$ at $64 \%\left(1119 \mathrm{t}-\mathrm{CO}_{2} / \mathrm{day}\right)$, and $\mathrm{CM} 1$ at $43 \%$ (749 $\mathrm{t}-\mathrm{CO}_{2} /$ day) (Fig.3). The results also show that as the participation and efficiency level increase the need to rely on waste treatment decreases. This directly influences generation of GHG in a positive way.

In 2025, at least 500 MSC base companies will be allocated in Cyberjaya with employer number of 120,000 . On top of that, nine tertiary educations that specialize in ICT with 30,000 students are already operating in the area. The sectors are projected to generate 1041t/year of e-waste. Waste manager should take this into serious consideration not that only e-waste is part of hazardous waste but the generation rate cover at least $0.1 \%$ of national ewaste generation. This is based from e-waste generation forecast by Department of Environment Malaysia that stated by 2020 generation of e-waste to be 1.1 million tonnes. One of measure that could be consider is adopting reduction at source method

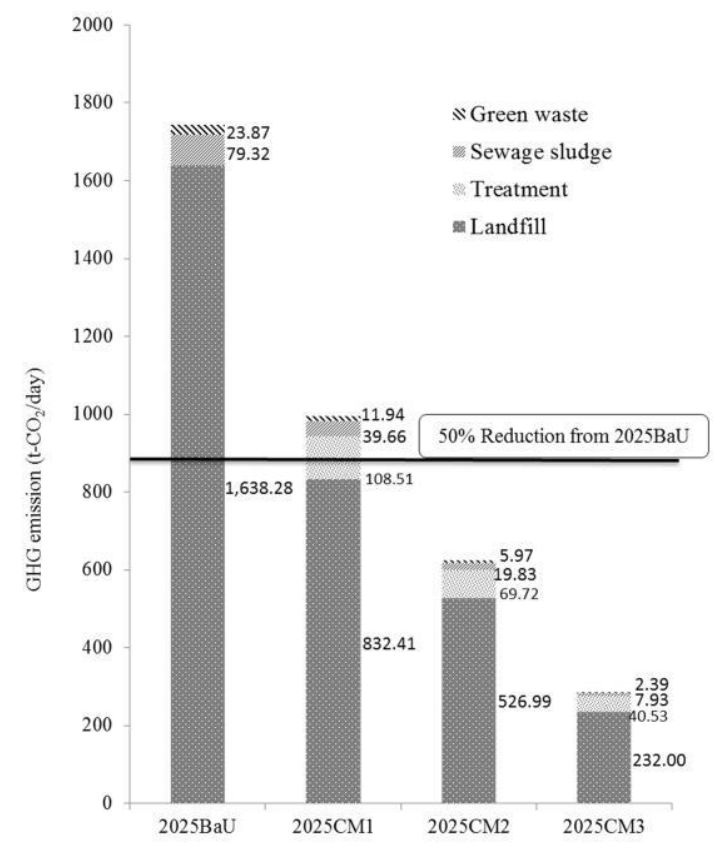

Fig.3 GHG emission by sector

such as utilization of rental and lease service, and sharing or circulating electrical and electronic equipment between offices.

The proposed scenarios provide us image of future society achievable through changes of waste treatment priority under combination of waste handling method. At high level of public participation in waste reduction at source and high accuracy of waste segregation, the needs of hightechnology treatment such as waste disposer and thermal treatment decreases. In contrast dependency on high-technology waste treatment will become crucial without support from public in waste reduction at source and segregation.

Our study is conducted based on local authority targets and plans for their future SWM therefore we regard our result as an easily adopted proposal into future Cyberjaya SWM implementation. Besides, during the study process, not only SWM authority but also all stakeholders - Cyberview and Setia Haruman, are closely involve through few series of focal group discussion to ensure the sustainability of Smart 3R Cyberjaya and its continuity with three other themes in this study of DGC2025. Additionally our three alternative counter measures (2025CM1, 2025CM2, 2025CM3) range widely between low, moderate and high law enforcement level, public participation and technology application to give the local authority wider scope and freedom of shaping their jurisdiction area. However cost factor was not considered in this 
study. It is because this study is a preliminary and baseline towards the feasibility study. Based on this snapshot of future achievable society, further study using backcasting method where pathway that linking the target year to the base year that consider all - technical, economic, legal, operational and scheduling factors will be carried out.

As a follow up of this preliminary study and to implement specific efforts towards the Low Carbon City, "Basic Research for Low Carbon City development in Putrajaya and Cyberjaya" was launched. This is a project by the Malaysian Government and supported by the Japanese governmental agency New Energy and Industrial Technology Development Organization (NEDO) ${ }^{8}$.

\section{CONCLUSION}

Smart 3R Cyberjaya study is carried out in conjunction with the feasibility study of Cyberjaya Digital Green City 2025. Our study objective is to come out with alternative SWM that fulfil the challenge of building both low-carbon and sound material cycle society. We set the target of building a zero emission society that depend less on landfill and actively practicing waste reduction at source. In term of quantitative we set the target of reducing $75 \%$ of waste sent to landfill site compare to 2025BaU. Smart 3R Cyberjaya includes all aspect of SWM management -generation, reduction, treatment and final landfill, from all waste source household, business, sewage sludge green area and e-waste.

Impact of combination of waste reduction at source actions and waste treatment facility on waste amount sent to landfill and GHG emission were evaluated. From three counter measures, the most waste to landfill and GHG emission reduction achievable in 2025CM3, 78\% (172 t/day) and 84\% (1459 t-CO2/day).

Even though our target of $75 \%$ reduction waste amount sent to final landfill compare to $2025 \mathrm{BaU}$ is only achievable at $2025 \mathrm{CM} 3$, waste reduction from other scenarios are also significant. Target of 50\% GHG reduction is achievable at all counter measure selection.

ACKNOWLEDGEMENT: This study is supported by Science and Technology Research Partnership for Sustainable Development (SATREPS).

\section{REFERENCES}

1) Barash, David: Peace and Conflict. Sage Publications. p. 547. ISBN 9780761925071, 2002

2) The World Bank, Malaysia Economic Monitor, November 2011 - Smart Cities, 2011

3) Cyberview Sdn. Bhd.: Cyberjaya City Survey 2010 Outcome of report, 2010

4) Office of the Prime Minister of Malaysia: Prime Minister speech in United Nation Climate Change Conference 2009 - " $15^{\text {th }}$ Conference of Parties (COP 15)", http://1malaysia.com.my/speeches/u-n-climate-changeconference-2009-15th-conference-of-parties-cop-15/; last view July 2012

5) Ministry of Finance Malaysia: The 2010 Budget Speech, October 2009

6) Ministry of Energy, Green Technology and Water: National Green Technology Policy, 2011

7) Y. Hayashi, J. J. Simson, K. Gomi, Y. Matsuoka : Development of a method to design a low-carbon society in small community and its application to Putrajaya, Malaysia, Journal of Japan Society of Civil Engineers, Ser. $G$ (Environmental Research), Vol. 67, No. 6,2011, pg.II_213-II_224, 2011.

8) The Japan Research Institute: Low Carbon City Action Planning Project in Putrajaya, Final Report, 2012

9) Setia Haruman Sdn. Bhd. : Cyberjaya Township, http://www.cyberjaya-msc.com/cyberjaya-town.asp; last view April 2012

10) MHLG: Ministry of Housing and Local Government, Malaysia : The Study on National Waste Minimisation in Malaysia, 2006.

11) Department of Statistic Malaysia : Report on Household Expenditure Survey Malaysia 1998/99, 2000.

12) Department of Statistic Malaysia : Report on Household Expenditure Survey 2004/05, 2006.

13) Department of Statistic Malaysia : Input-Output Tables Malaysia 1991, 2002.

14) Department of Statistic Malaysia : Input-Output Tables Malaysia 2000, 2005.

15) Department of Statistic Malaysia : Annual Survey of Manufacturing Industries 2005, 2006.

16) Department of Statistic Malaysia : Input-Output Tables Malaysia 2005, 2010.

17) http://www.kokuyo-furniture.co.jp/; last view April 2012

18) Siti Norbaizura MD. R, T. Fujiwara, T. Hamada : Impact of 3R Implementation on Solid Waste Management - Case Study of Putrajaya Malaysia, World Congress of International Solid Waste Association, 2011.

19) Department of Environment Malaysia: The E-waste Inventory Project in Malaysia, 2007

20) International Law Book Services : Solid Waste and Public Cleansing Management Act 2007 (Act 672) \& Solid Waste and Public Cleansing Management Corporation Act 2007 (Act 673), 2009.

21) Option Database for Jemai-LCA Pro (in Japanese): 社団法 人産業環境管理協会

22) Formulas, Models and Tables in Environmental Engineering (in Japanese): 土木学会

(Received April 21, 2012)

(Accepted July 27, 2012) 